\title{
Cancer Patients for Pain Complementaries and Integrated Approaches Used in Palliative Care
}

\author{
Fadime Toru* , Ebru Yıldız \\ Fundamental Nursing Department, Mersin University, Mersin, Turkey \\ Email address: \\ erzurum33_33@hotmail.com (F. Toru), ebruyildiz@mersin.edu.tr (E. Yıldız) \\ ${ }^{*}$ Corresponding author
}

\section{To cite this article:}

Fadime Toru, Ebru Yıldız. Cancer Patients for Pain Complementaries and Integrated Approaches Used in Palliative Care. American Journal of Life Sciences. Vol. 7, No. 6, 2019, pp. 100-109. doi: 10.11648/j.ajls.20190706.11

Received: August 12, 2019; Accepted: September 3, 2019; Published: October 31, 2019

\begin{abstract}
Nowadays, nursing is an effective and indispensable member of the health team both in Turkey and in the world. Because people need care practices any point their life experiences that end in health, well-being, discomfort, disease and death. While palliative care practices, which are seen as key point of nursing practices among care needs, are only care for patients in the last stage of life, it is opinion that it is necessary to reduce the pain level and improve the quality of life according to the palliative care principles. Recent cancer patients constitute a significant part of patients receiving palliative care and have problems due to symptoms caused by chemotherapy treatment. Pain is the most feared outcome of these symptoms. Pharmacological treatment, pain, community, despite various educational practices, patients often complain of problem. It is important to create complementary and integrated approaches to palliative care for pain, which significantly affects the daily living activities and quality of life of patients. In addition, complementary and integrated care practices in palliative care help to prevent nursing from being a job-oriented profession and to focus on nursing role and practices, not medical applications.
\end{abstract}

Keywords: Pain, Cancer, Palliative Care, Complementary and İntegrated Approaches

\section{Introduction}

In recent years, significant changes have occurred in sociocultural and population characteristics and medical diagnosis / treatment methods of societies. One of the important issues in health today is to improve the quality of life with palliative care practices. For this, individuals need to be able to perform self-care, prevent accidents and disabilities, and increase their capacity to work. In parallel with all these changes, the concept of palliative approach is gaining importance [1-2]. While palliative care practices have been performed only for the patients in the last stage of life, it is now advocated that palliative care should be applied as early as possible in patients who are aimed at reducing the pain level and increasing the quality of life according to the principles of palliative care [23]. In recent years, with the prolongation of life expectancy and technological advances, the concept of palliative care has become increasingly important. Palliative care practices have developed rapidly in recent years as a result of the increase in the number of individuals living with chronic and lifethreatening diseases and the attempts of health professionals to provide palliative care [1-3]. End-stage cancer patients constitute an important part of the patients receiving palliative care and have problems due to both cancer and the symptoms of the side effects of chemotherapy treatment. One of these symptoms is pain. Pain considered by patients as one of the most feared outcomes of cancer; It is a problem that approximately $60 \%$ of patients complain of despite pharmacological treatments, pain-related communities, and various interventions and educational practices. Cancer pain significantly affects the daily activities and quality of life of the patient. Therefore, it is important to establish palliative approaches to pain in cancer patients.

\section{Method}

\subsection{Inclusion Criteria}

The following criteria were taken into consideration in the 
selection of the articles to be included in the study;

(1) The results of this study suggest complementary and integrative approaches to pain used in palliative care in cancer patients;

(2) the language of publication is Turkish or English;

(3) published in the last decade (2008-2018);

(4) access to the full text. Randomized controlled trials (RCTs) and quasi-experimental studies (LDS) were included in the study.

\subsection{Reasons Not to Include in Research}

Research and observations investigating complementary and integrated approach interventions to cancer patients receiving palliative care have not been included in the systematic review. The studies conducted in the last decade have been taken into consideration in the evaluation of current information. There is no study whose title or summary is not clear, full texts cannot be reached and the publication language is not Turkish / English.

\subsection{Research and Selection of Studies}

\subsubsection{Sample Definition}

Studies; In October 2017-March 2018 "OVID”, "Medline”, "Cochrane", "Pubmed", "Wiley Online Library" databases and "Google Scholar" and "YÖKSİS Theses" were selected. The following keywords were used; Researches in graduate and doctoral theses and nursing journals were also preferred. The titles and abstracts of all related articles identified by electronic search were independently reviewed by the researchers. The investigations of the researchers were then compared and 556 references were eliminated from the 516 studies included in the exclusion criteria, and the full texts of 21 studies were taken as the source for systematic review. Each of the selected articles includes research that includes a complementary and integrative approach to pain in cancer patients receiving palliative care.

\subsubsection{Data Analysis}

A standard data summary form was developed to summarize the data and the data was evaluated accordingly. The studies included independently by the researchers were summarized according to the data summarization form. Then the abstracts were compared and a consensus was established among the researchers.

In the content of data summarization form;

a. Authors and year of the study,

b. The name of the study and sample size,

c. Design of the study,

d. Dependent variables,

e. Method of study,

f. The findings of the study were included.

In the studies included in this systematic study, metaanalysis could not be performed because the characteristics of the participants, intervention and measurement methods applied were not the same.

\section{Result}

Complementary and Integrated Approaches to Pain in Cancer Patients

Despite advances in science and technology in the world, cancer has become one of the most important health problems, according to World Health Organization (WHO) 2017 data, the second leading cause of death among heart diseases and causes $22.3 \%$ of all deaths [2-5]. Millions of people are diagnosed with cancer every year in the world and more than half of these patients die because of cancer [4-5]. Despite advances in medical and health sciences, cancer continues to be a process that includes many physical, psychological, social and spiritual difficulties for patients and their relatives, from the time of diagnosis, at the time of death and at the time of mourning. In addition, it negatively affects the quality of life and causes many disturbing symptoms and leads to a vicious cycle [6-7]. "Pain. Is one of the factors that frequently trigger this vicious cycle. Pain; It is described as an undesirable psychological experience by patients presenting or occurring with tissue damage or can be identified by this damage [7-8]. Pain experienced by cancer patients is identified as an important problem and its incidence is reported to be more than $90 \%$ in advanced patients and $50 \%$ in patients with metastases [8-9]. In a systematic review by Beuken, Everdingen, \& De Rijke (2007) examining the prevalence of pain in cancer patients; pain was found to be $33 \%$ in patients receiving medication, $59 \%$ in patients receiving chemotherapy, $64 \%$ in patients with endstage disease, and 53\% in all disease stages [10]. Kara and Fesci (2008), 53.6\% of patients receiving chemotherapy treatment, and $80 \%$ of patients diagnosed with advanced cancer experienced pain during the course of the disease [11]. Breivik, Cherny, \& Collett (2009) in a study of 5084 cancer patients, in the last month, $56 \%$ of patients experiencing progressive pain from moderate to severe levels and $69 \%$ of the daily life activities were found to be difficult due to cancer. pain has been reported to affect $80-90 \%$ of patients [12]. Uysal et al. (2015), it was found that $90 \%$ of cancer patients who received palliative care complained of pain [13]. Beuken V and et al. (2016) in a study examining the prevalence of pain in cancer patients; pain was found to be $39.3 \%$ in patients receiving medication, $55 \%$ in patients receiving chemotherapy, and $66.4 \%$ in patients with metastasis in the late and advanced stages [14].

According to the data obtained from the literature, the most common symptom experienced by cancer patients is pain; In addition to medical treatments, it is supported by many complementary therapies $[3,15]$. Medicines are widely used as a pharmacological method in medical treatment. Pharmacological methods in pain control are the most preferred treatment modality because of their rapid effect and simple application. The unconscious and intense use of analgesics used as pharmacological methods causes addiction in the individual and sudden release causes various physical symptoms. Therefore, it is recommended that drug use should be performed under the supervision of a doctor and 
nurse [13, 15-16]. Another method used alone or in combination with pharmacological treatment to reduce and control pain level is non-pharmacological methods. The frequency of the use of non-pharmacological methods has been increasing in recent years especially in order to reduce the rate of analgesic use and increase the quality of life [1718]. The importance of palliative care practices in meeting the physical, psychological, social and psychological needs of patients and their relatives during the treatment period from the time of diagnosis, to the time of death and after the mourning period is undeniable since the patients whose therapeutic approaches are over $[6-7,19]$. WHO palliative care; It is defined as an approach aimed at the early detection and treatment of physical, psychological, social and psychological problems, especially pain, and to improve the quality of life of patients and their relatives who face a lifethreatening illness [20]. Since the development of palliative care practices prolongs the life expectancy of cancer patients, cancer patients experience pain longer. Palliative care practices are not only care given in the terminal period of life, but are also a method of care that should be combined with drug methods and life-prolonging treatment at every stage of the disease $[13,19,21]$.

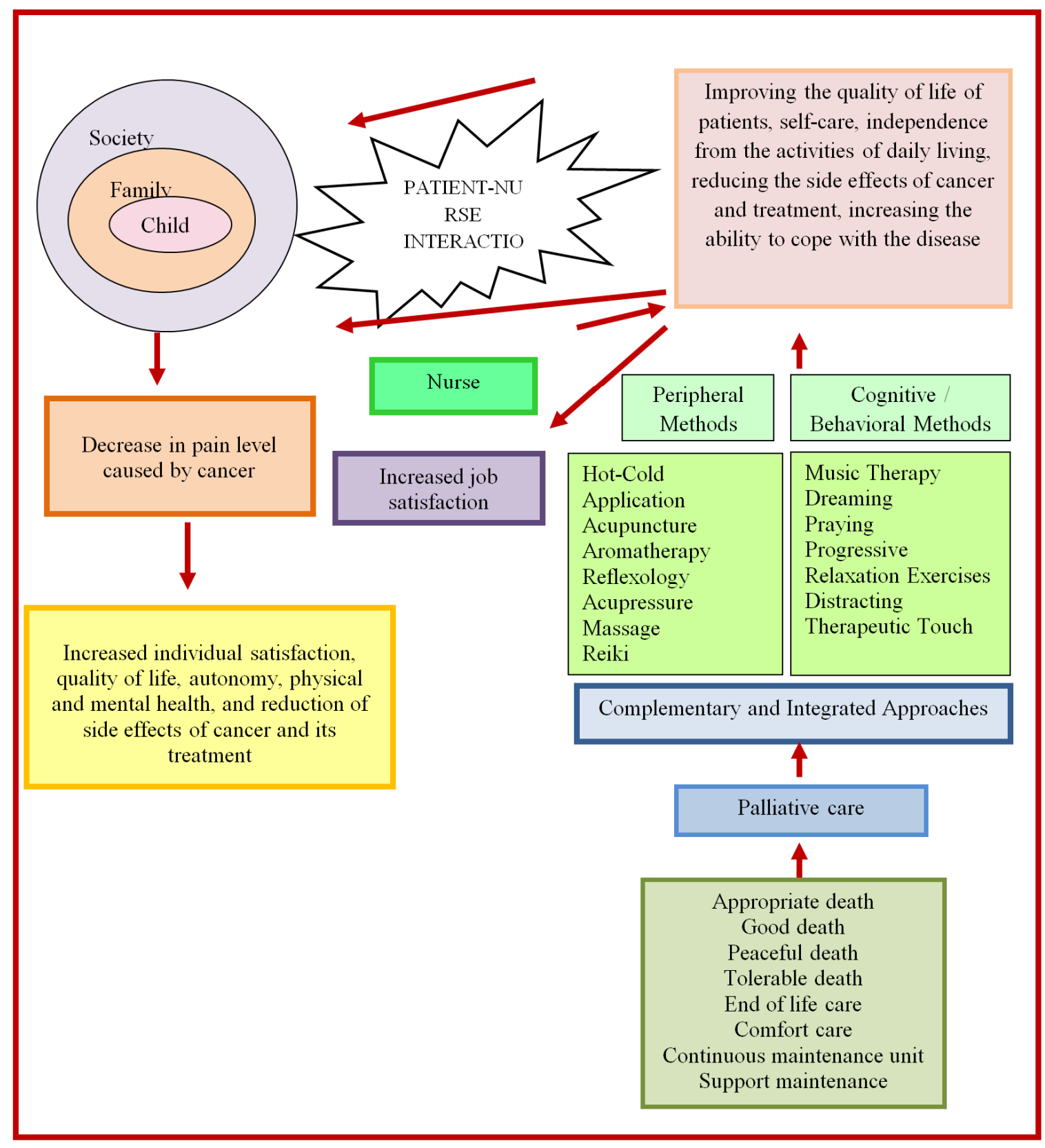

Figure 1. Concept map: Patient-nurse interaction and results related to complementary and integrated approaches in palliative care.

The use of pharmacological and non-pharmacological methods as a palliative approach to pain in cancer patients provides the patient with a quality life that he can perform daily life activities without difficulty [18-19]. Nonpharmacological methods are divided into peripheral (skin stimulation) methods and cognitive / behavioral methods and 
are shown in Figure 1. Peripheral methods, according to the gate-control theory, by inhibiting the small diameter fibers carrying the message of pain by eliminating the stimulus felt as pain, cognitive / behavioral methods; it reduces or controls pain level by creating changes in emotional factors [22-24]. Peripheral methods include hot-cold treatments, acupuncture, aromatherapy, reflexology, acupressure, massage and reiki; in cognitive / behavioral methods; music therapy, dreaming, praying, progressive relaxation exercises, attention and therapeutic touch [25-27].

\section{Discussion}

\subsection{Pain Control Methods}

\subsubsection{Peripheral (Skin Stimulation) Methods}

\section{(i). Hot and Cold Applications}

In the oldest data about human life, hot and cold applications, which are known to be used in the treatment of diseases, are an effective and widespread method used to relieve pain $[22,24]$. The hot application by means of heated hot water packs filled with water, hot moist compresses, electric heating packs, chemical gel packs and hydrotherapy provides vasodilation, dissolves muscle spasm, increases blood flow, reduces the effects of pressure, tension and hypoxia on the nerve endings, and pain in that area. increases pain threshold and reduces pain [22, 24, 28, 29]. Cold application is carried out with ice packs, chilled chemical gel packs and cold baths, and it is effective in decreasing the heat of the receptors in the body, increasing skin sensitivity and creating vasoconstriction effect and reducing edema, blood flow and pain level $[22,28]$. In the studies, it was determined that the application of hot-cold reduces pain, accelerates circulation and provides relief [30-32].

\section{(ii). Acupuncture}

Acupuncture, which is one of the important elements of traditional Chinese medicine, is a scientific treatment that enables the body to regain its balance as a result of stimulation of special points in the body with needles. Acupuncture is effective in reducing chronic pain in cancer patients by exerting secretion of enkephalins and increasing serotonin levels from endogenous opioids known to have an effect on regulating mental and psychological state [33-35]. In studies with cancer patients with pain, acupuncture has been found to be a complementary, self-medicating, nonmedication treatment that reduces cancer-related symptoms (pain, digestive problems, neuropathy), and is selfmedicating [36-39].

\section{(iii). Aromatherapy}

Aromatherapy, which is used to improve, balance and relieve symptoms of individuals' physical, psychological, and spiritual health, is an essential oil obtained from plants; massage, inhalation, compress and bath methods such as the application of the body [40-41]. Some analgesic components in oils, endorphins in the brain stem, such as seratonin, noradrenaline and dopamine affect the release of substances and as a result of the emergence of analgesic properties due to the emergence of analgesic properties are used today for therapeutic purposes to control pain [24, 42, 43]. In studies examining the effect of aromatherapy in patients receiving chemotherapy, it was found that aromatherapy reduces pain and provides relief and relaxation of the patient [44-47].

\section{(iv). Reflexology}

Reflexology, a treatment method that involves balancing the blood circulation and nervous system, alleviating the side effects of chemotherapy, improving the quality of life, regulating the function of the sympathetic and parasympathetic nervous system, stimulates the release of endorphins in the body and stimulates the release of endorphins in cancer patients [48, 49]. In studies conducted with patients with cancer pain, it was found that reflexology application decreased the level of pain, anxiety and fatigue by taking the attention in another direction, had a positive effect on the daily life of the patient and increased sleep quality [50-55].

\section{(v). Acupressure}

The aim of acupressure which is a noninvasive treatment method applied by applying pressure with finger, palm or special bands to certain points that provide energy flow in the body, activating blood circulation, providing neurological effect and relaxation, thus reducing the pain of the individual and thus maintaining the normal functions of the body [5658]. In studies with patients with cancer pain; It is stated that acupressure application reduces pain and provides relief by reducing tension in muscles and this result is the preliminary evidence of acupressure's pain reduction effect [59-61].

\section{(vi). Massage}

Massage used by many cultures as a treatment art because of its therapeutic and relaxing effect; By activating the door control system in the body, endorphin hormone secretion by increasing the pain threshold reduces the perception of pain [24-27]. In studies conducted with patients with cancer pain, it has been found that massage application increases the pain threshold and reduces the pain level [62-63]. Cutshall, Mahapatra, \& Hynes (2017) concluded that there is insufficient evidence about the use of massage in the clinical practice of pain management of cancer patients receiving outpatient chemotherapy and there are few studies on the subject [64].

\section{(vii). Reiki}

Reiki application, called healing method, is used to balance the energy flow in the individual and the practitioner tries to re-circulate the energy in the blocked channels by sending his own energy to the energy points [65-67]. In the researches, it was found that reiki application is a practice that provides harmony between body, mind and soul, shortens the length of hospital stay, increases patient satisfaction, provides relief, facilitates transition to sleep, reduces pain, fatigue, nausea, emotional distress and anxiety 
levels [68-71].

\subsection{Cognitive / Behavioral Methods}

\subsubsection{Music Therapy}

Music therapy is one of the oldest aesthetic treatment methods that provide benefits by meeting the physical, sensory, cognitive and social needs of patients and maintaining their mental health $[18,72]$. In the studies performed, cancer patients felt that their pain was alleviated by listening to music and feeling that their bodies were relaxed. In addition, it was emphasized that music therapy is an effective, non-invasive and inexpensive application to control and reduce cancer pain, but there is a need for studies in which patients are asked about their music preferences [73-75]. In another study, it was found that music was effective in reducing pain in cancer patients, but the effect of music was found to be higher and more effective in the group preferred by the patients [76-78].

\subsubsection{Dreaming}

It is a way of thinking which is used regularly by most people, and it is a method of focusing on the attention that provides relaxation and desire to control in the individual. The individual imagines the pleasant scenes such as the sea, the lake and the forest, away from the painful stimulus or imagines that the painful area has turned into ice. It is thought that dreaming together with rhythmic breathing and relaxation may have positive effects on strengthening the effects of treatment, reducing pain expectation and side effects by supporting the patient's participation in individual care $[23,79,80]$.

\subsubsection{Praying}

Cancer is a health problem that causes pain, which is difficult to cope with intensive treatment practices by patients and their relatives, creates stress, and affects life by causing various physical, psychological, social and spiritual problems $[79,81,82]$. Patients use a variety of coping methods to reduce and control the symptoms caused by cancer. It was observed that the physical, social, spiritual and spiritual conditions of the patients who used the methods of prayer and coping with belief were improved [81-83]. In a study conducted with women with breast cancer, it was found that prayer was important for $88 \%$ of women and $85 \%$ was an aid in coping with pain and other symptoms [82]. In other studies, it was emphasized that praying has an important effect on the coping and acceptance of the patients who have problems in accepting the disease such as cancer, it has been seen that it increases the quality of life, hope of getting rid of the disease and the ability to make meaning from the disease, but studies about the effect of praying in the management of pain in cancer patients are insufficient [81-83].

\subsubsection{Progressive Relaxation Exercises}

Progressive relaxation exercises, which are one of the cognitive / behavioral treatment methods, provide voluntary contraction and passive loosening of large muscles voluntarily, resulting in a decrease in the functions of the sympathetic nervous system and an increase in the functions of the parasympathetic nervous system. In the studies carried out in cancer patients; progressive relaxation exercises have been found to reduce pain levels, effective, easy to apply and inexpensive method [84-85].

\subsubsection{Draw Attention}

The distraction method, which enables the patient's attention to be focused in a different place, enables the control and reduction of the symptoms experienced by the individual [86-87]. Although this method is not a method that directly reduces pain, it increases the pain threshold and increases its resistance to pain [23, 88]. It includes multiple applications such as watching a movie, listening to funny stories or music, having pictures taken by the individual. A method that focuses on the individual's coping with the symptoms caused by chemotherapy; it increases the individual's sense of control, activity level and work capacity, and reduces the feeling of weakness, side effects of pharmacological methods, and the level of pain and anxiety $[23,88,89]$.

\subsubsection{Therapeutic Touch}

Therapeutic touch, which positively affects patients' consciousness, aims to help individuals, is considered to be an effective method to improve comfort and well-being, and to integrate energy-enhancing, regulating, balancing and preserving with hands to treat symptoms caused by imbalance in energy fields. is a treatment method [90-91]. Tabatabaee et al. (2016), in his study, it was found that a total of seven sessions of therapeutic touch application to cancer patients for four weeks positively affected the patients physically and psychologically, decreased the pain level and was one of the important cognitive / behavioral methods frequently used by health professionals in recent years [92].

\section{Conclusion}

In this review, it is seen that the peripheral and cognitive methods used in palliative care in cancer patients are used to reduce and control pain level and it is confirmed that these methods have a positive or negative effect on pain level. Based on the findings obtained from the review, peripheral methods include "hot-cold applications, acupuncture, aromatherapy, reflexology, acupressure, massage, reiki"; It was concluded that terapi music therapy, daydreaming, praying, progressive relaxation exercises, distracting and therapeutic touch den which are cognitive methods provide a significant decrease in the perceived pain level of the patients. Peripheral and cognitive methods may contribute positively to reducing the pain level of cancer patients experiencing pain, including palliative care patients. In this context, it is recommended to conduct large sample studies to determine the effect of peripheral and cognitive methods on pain level and other symptoms, to determine effective methods, to test these methods in clinical settings and to use them in clinics. 


\section{Recommendations}

For palliative treatment of cancer patients, good planning and nurses' training and experience are needed. Improving the quality of life, relieving symptoms, and supporting the patients and their relatives in a way that is worthy of human dignity is very important in patients who have no chance of cure. It is suggested that palliative treatment of cancer patients can be provided with the active support of not only nurses engaged in oncology, but also all other branches and physicians.

Table 1. Studies Related to the Subject.

\begin{tabular}{|c|c|c|c|c|}
\hline $\begin{array}{l}\text { Author / } \\
\text { Year }\end{array}$ & $\begin{array}{l}\text { Type of } \\
\text { Research }\end{array}$ & Number and Group of Samples & Intervention & Results \\
\hline $\begin{array}{l}\text { Blyth et al. } \\
(2005)\end{array}$ & $\begin{array}{l}\text { Community } \\
\text { based work }\end{array}$ & $\begin{array}{l}474 \text { cancer patients experiencing } \\
\text { pain }\end{array}$ & $\begin{array}{l}\text { The methods used when patients } \\
\text { experienced pain were determined. }\end{array}$ & $\begin{array}{l}\text { It was determined that } 47 \% \text { of the patients } \\
\text { were using medication, } 31.5 \% \text { were } \\
\text { resting, } 25.8 \% \text { were exercising, and } 23.4 \% \\
\text { were doing hot / cold treatment to reduce } \\
\text { the pain level. As a result of the study, it } \\
\text { was found that the application of hot and } \\
\text { cold significantly reduced the pain level of } \\
\text { the patients }(\mathrm{p} \leq 0.05) \text {. }\end{array}$ \\
\hline $\begin{array}{l}\text { Bacaksiz et } \\
\text { al. } \\
(2008)\end{array}$ & $\begin{array}{l}\text { Descriptive } \\
\text { Work }\end{array}$ & 199 patients & $\begin{array}{l}\text { The methods used by the nurses in } \\
\text { patients experiencing pain were } \\
\text { determined. }\end{array}$ & $\begin{array}{l}\text { It was determined that the application of } \\
\text { hot and cold reduces the pain level of the } \\
\text { patient, accelerates circulation and } \\
\text { provides relief. }\end{array}$ \\
\hline $\begin{array}{l}\text { Chen et al. } \\
(2013)\end{array}$ & $\begin{array}{l}\text { Randomized } \\
\text { controlled } \\
\text { study (RCS) }\end{array}$ & $\begin{array}{l}60 \text { patients ( } 30 \text { patients in the } \\
\text { study, } 30 \text { patients in the control } \\
\text { group) }\end{array}$ & $\begin{array}{l}\text { The study group received acupuncture } \\
\text { for } 30 \text { minutes; control group received } \\
\text { standard chemotherapy treatment. }\end{array}$ & $\begin{array}{l}\text { It was determined that acupuncture } \\
\text { application significantly reduced cancer- } \\
\text { related pain levels in patients ( } \mathrm{p} \leq 0.05) \text {, } \\
\text { and it was determined that the organism } \\
\text { was a self-healing complementary method. }\end{array}$ \\
\hline $\begin{array}{l}\text { Tofthagen } \\
\text { et al. } \\
(2015)\end{array}$ & $\mathrm{RCS}$ & $\begin{array}{l}50 \text { cancer patients ( } 25 \text { patients in } \\
\text { the study, } 25 \text { patients in the } \\
\text { control group) }\end{array}$ & $\begin{array}{l}\text { The study group received acupuncture } \\
\text { for } 4 \text { weeks; control group received } \\
\text { only standard chemotherapy } \\
\text { treatment. }\end{array}$ & $\begin{array}{l}\text { Cancer-related symptoms (pain, digestive } \\
\text { system problems, neuropathy) were } \\
\text { significantly reduced in patients receiving } \\
\text { acupuncture }(\mathrm{p} \leq 0.05) \text {. }\end{array}$ \\
\hline $\begin{array}{l}\text { Babashahi } \\
\text { et al. } \\
(2013)\end{array}$ & $\mathrm{RCS}$ & $\begin{array}{l}40 \text { Acute Myeloid Leukemia } \\
\text { (AML) patients ( } 20 \text { patients in the } \\
\text { study, } 20 \text { patients in the control } \\
\text { group) }\end{array}$ & $\begin{array}{l}\text { The study group received } 20 \text { minutes } \\
\text { of lavender aromatherapy for } 4 \text { weeks; } \\
\text { control group received only standard } \\
\text { chemotherapy treatment. }\end{array}$ & $\begin{array}{l}\text { It was determined that lavender } \\
\text { aromatherapy application significantly } \\
\text { reduced pain }(\mathrm{p} \leq 0.05) \text { and provided relief } \\
\text { and relaxation. }\end{array}$ \\
\hline $\begin{array}{l}\text { Dikmen \& } \\
\text { Terzioğlu } \\
(2018)\end{array}$ & $\mathrm{RCS}$ & $\begin{array}{l}80 \text { gynecological cancer patients } \\
\text { ( } 20 \text { patients reflexology, } 20 \\
\text { patients progressive relaxation } \\
\text { exercise group, } 20 \text { patients } \\
\text { reflexology and progressive } \\
\text { relaxation exercise was applied } \\
\text { together, } 20 \text { patients control } \\
\text { group) }\end{array}$ & $\begin{array}{l}\text { The study group was divided into } \\
\text { three groups (reflexology group, } \\
\text { progressive relaxation exercise group, } \\
\text { reflexology and progressive relaxation } \\
\text { exercise group). }\end{array}$ & $\begin{array}{l}\text { The control group received standard } \\
\text { treatment. In the group where reflexology } \\
\text { and progressive relaxation exercises were } \\
\text { applied together; pain and fatigue levels } \\
\text { decreased significantly ( } \mathrm{p} \leq 0.05) \text { and } \\
\text { quality of life increased }(\mathrm{p} \leq 0.05) \text {. }\end{array}$ \\
\hline $\begin{array}{l}\text { Tarrasch et } \\
\text { al. }(2018)\end{array}$ & $\mathrm{RCS}$ & $\begin{array}{l}72 \text { breast cancer patients ( } 36 \\
\text { patients in the study, } 36 \text { patients } \\
\text { in the control group) }\end{array}$ & $\begin{array}{l}\text { The study group received reflexology } \\
\text { for } 10 \text { weeks and the control group } \\
\text { received only standard treatment. }\end{array}$ & $\begin{array}{l}\text { It was found that cancer insomnia, pain } \\
\text { and fatigue levels decreased significantly } \\
\text { in patients undergoing reflexology } \\
(\mathrm{p} \leq 0.05) \text {. }\end{array}$ \\
\hline $\begin{array}{l}\text { Tsay et al. } \\
(2008)\end{array}$ & $\mathrm{RCS}$ & $\begin{array}{l}61 \text { operated gastric and liver } \\
\text { cancer patients ( } 31 \text { patients in the } \\
\text { study, } 30 \text { patients in the control } \\
\text { group) }\end{array}$ & $\begin{array}{l}\text { The study group received reflexology } \\
\text { for } 20 \text { minutes for } 3 \text { days on days } 2,3 \\
\text { and } 4 \text { postoperatively; control group } \\
\text { received standard treatment. }\end{array}$ & $\begin{array}{l}\text { In the reflexology group; analgesia intake, } \\
\text { pain and anxiety levels were significantly } \\
\text { decreased }(\mathrm{p} \leq 0.05)\end{array}$ \\
\hline $\begin{array}{l}\text { Hodgson \& } \\
\text { Lafferty } \\
(2012)\end{array}$ & RCS & $\begin{array}{l}18 \text { individuals with cancer } \\
\text { treatment completed in nursing } \\
\text { homes }\end{array}$ & $\begin{array}{l}\text { The study group was divided into } 2 \\
\text { groups. One group received } 20 \\
\text { minutes of reflexology, the other } \\
\text { group received } 20 \text { minutes of } \\
\text { massage, and the control group } \\
\text { received standard care. }\end{array}$ & $\begin{array}{l}\text { There was a significant decrease in } \\
\text { cortisol hormone level }(\mathrm{p} \leq 0.05) \text { and pain } \\
\text { level ( } \mathrm{p} \leq 0.05) \text { in reflexology and Swedish } \\
\text { massage groups. }\end{array}$ \\
\hline $\begin{array}{l}\text { Chien et al. } \\
(2015)\end{array}$ & Pilot Work & 31 breast cancer patients & $\begin{array}{l}31 \text { patients underwent acupressure for } \\
3 \text { days in } 7 \text { days and } 3 \text { sessions. }\end{array}$ & $\begin{array}{l}\text { After acupressure treatment, there was a } \\
\text { significant decrease in sleep quality, pain } \\
\text { and fatigue }(p \leq 0.05) \text {. }\end{array}$ \\
\hline $\begin{array}{l}\text { Sharif Nia } \\
\text { et al. (2017) }\end{array}$ & $\mathrm{RCS}$ & $\begin{array}{l}100 \text { leukemia patients ( } 50 \\
\text { patients study, } 50 \text { patients control } \\
\text { group) }\end{array}$ & $\begin{array}{l}\text { The study group received acupressure } \\
\text { for } 8 \text { minutes in } 4 \text { weeks and } 12 \\
\text { sessions, while the control group } \\
\text { received only standard chemotherapy } \\
\text { treatment. }\end{array}$ & $\begin{array}{l}\text { It was found that there was a significant } \\
\text { decrease in the short-term pain level in } \\
\text { patients undergoing acupressure }(\mathrm{p} \leq 0.05) \text {. }\end{array}$ \\
\hline $\begin{array}{l}\text { Serçe et al. } \\
(2018)\end{array}$ & $\mathrm{RCS}$ & $\begin{array}{l}40 \text { Cancer patients with bone } \\
\text { metastasis ( } 20 \text { patients study, } 20\end{array}$ & $\begin{array}{l}\text { The study group received acupressure } \\
\text { for } 10 \text { minutes for } 8 \text { days each }\end{array}$ & $\begin{array}{l}\text { There was a significant decrease in pain } \\
\text { level }(\mathrm{p} \leq 0.05) \text { in patients receiving }\end{array}$ \\
\hline
\end{tabular}




\begin{tabular}{|c|c|c|c|c|}
\hline $\begin{array}{l}\text { Author / } \\
\text { Year }\end{array}$ & $\begin{array}{l}\text { Type of } \\
\text { Research }\end{array}$ & Number and Group of Samples & Intervention & Results \\
\hline & & patients control) & $\begin{array}{l}\text { session; control group received only } \\
\text { standard treatment. }\end{array}$ & acupressure. \\
\hline $\begin{array}{l}\text { Jane et al. } \\
(2011)\end{array}$ & RCS & $\begin{array}{l}72 \text { Cancer patients with bone } \\
\text { metastasis ( } 36 \text { patients in the } \\
\text { study, } 36 \text { patients in the control } \\
\text { group) }\end{array}$ & $\begin{array}{l}45 \text { minutes of massage for } 5 \text { days; } \\
\text { control group received standard } \\
\text { chemotherapy treatment. }\end{array}$ & $\begin{array}{l}\text { There was a significant decrease in pain } \\
\text { level ( } \leq \leq 0.05 \text { ), a significant increase in } \\
\text { sleep quality ( } \mathrm{p} \leq 0.05 \text { ), and improvement } \\
\text { in mood and relaxation in massage } \\
\text { patients. }\end{array}$ \\
\hline $\begin{array}{l}\text { Toth et al. } \\
\text { (2013) }\end{array}$ & RCS & $\begin{array}{l}29 \text { Patients with metastatic cancer } \\
\text { ( } 20 \text { patients study, } 9 \text { patients } \\
\text { control group) }\end{array}$ & $\begin{array}{l}\text { The study group received } 3 \text { sessions } \\
\text { of } 15-45 \text { minutes of massage each } \\
\text { week; control group received only } \\
\text { standard treatment. }\end{array}$ & $\begin{array}{l}\text { There was a significant decrease in pain } \\
\text { level }(p \leq 0.05) \text { and a significant increase in } \\
\text { sleep and quality of life }(p \leq 0.05) \text { in } \\
\text { patients receiving massage. }\end{array}$ \\
\hline $\begin{array}{l}\text { Demir et al. } \\
(2015)\end{array}$ & $\mathrm{RCS}$ & $\begin{array}{l}18 \text { cancer patients ( } 8 \text { patients } \\
\text { study, } 10 \text { patients control group) }\end{array}$ & $\begin{array}{l}\text { The study group was reiki } 30 \text { minutes } \\
\text { each evening for a week; control } \\
\text { group received only standard } \\
\text { treatment. }\end{array}$ & $\begin{array}{l}\text { There was a significant decrease in } \\
\text { fatigue, pain and anxiety levels in the reiki } \\
\text { group ( } \mathrm{p} \leq 0.05) \text {. }\end{array}$ \\
\hline $\begin{array}{l}\text { Kirshbaum } \\
\text { et al. (2016) }\end{array}$ & $\begin{array}{l}\text { Cross- } \\
\text { sectional } \\
\text { Study }\end{array}$ & 10 breast cancer women patients & $\begin{array}{l}10 \text { breast cancer patients received } 30 \\
\text { minutes of reiki. }\end{array}$ & $\begin{array}{l}\text { It was found that there was a significant } \\
\text { decrease in the short-term pain level in } \\
\text { patients who underwent reiki treatment } \\
(\mathrm{p} \leq 0.05) \text {. }\end{array}$ \\
\hline $\begin{array}{l}\text { Rosenbaum } \\
\& \text { Velde } \\
\text { (2016) }\end{array}$ & RCS & $\begin{array}{l}150 \text { cancer patients ( } 50 \text { patients } \\
\text { yoga, } 50 \text { patients massage, } 50 \\
\text { patients reiki group) }\end{array}$ & $\begin{array}{l}\text { The effects of reiki, massage and yoga } \\
\text { on pain levels were examined. }\end{array}$ & $\begin{array}{l}\text { Reiki treatment was found to be more } \\
\text { effective in reducing cancer pain } \\
\text { significantly ( } \mathrm{p} \leq 0.05) \text { compared to the } \\
\text { other two applications. }\end{array}$ \\
\hline $\begin{array}{l}\text { Lee et al. } \\
\text { (2015) }\end{array}$ & Case study & 2 patients with ovarian cancer & $\begin{array}{l}\text { Two ovarian cancer patients were } \\
\text { given } 4 \text { sessions of oriental music for } \\
2 \text { weeks, } 2 \text { hours and } 1 \text { hour. }\end{array}$ & $\begin{array}{l}\text { In a case study examining the effect of } \\
\text { music therapy in patients with ovarian } \\
\text { cancer, it was found that music played } \\
\text { during chemotherapy significantly reduced } \\
\text { pain levels in patients ( } \leq \leq 0.05 \text { ). }\end{array}$ \\
\hline $\begin{array}{l}\text { Jourt- } \\
\text { Pineaua et } \\
\text { al. (2013) }\end{array}$ & $\begin{array}{l}\text { Prospective } \\
\text { study }\end{array}$ & $\begin{array}{l}24 \text { cancer patients receiving } \\
\text { chemotherapy }\end{array}$ & $\begin{array}{l}24 \text { patients who had received } \\
\text { chemotherapy treatment had } 30 \\
\text { minutes of music listening before each } \\
\text { chemotherapy session. }\end{array}$ & $\begin{array}{l}\text { It was found that the music played during } \\
\text { chemotherapy significantly decreased the } \\
\text { pain level in patients ( } \leq \leq 0.05 \text { ). }\end{array}$ \\
\hline $\begin{array}{l}\text { Kurt \& } \\
\text { Kapucu } \\
(2018)\end{array}$ & $\mathrm{RCS}$ & $\begin{array}{l}49 \text { breast cancer patients } \\
\text { receiving chemotherapy }(25 \\
\text { patients in the study, } 24 \text { patients } \\
\text { in the control group) }\end{array}$ & $\begin{array}{l}\text { The study group consisted of } 27 \\
\text { minutes of progressive relaxation } \\
\text { exercise during } 4 \text { chemotherapy } \\
\text { treatments; control group received } \\
\text { only standard chemotherapy } \\
\text { treatment. }\end{array}$ & $\begin{array}{l}\text { Pain, anxiety and fatigue levels were } \\
\text { significantly decreased ( } \leq \leq 0.05 \text { ) and sleep } \\
\text { quality was significantly increased } \\
\text { ( } \leq 0.05 \text { ) in the progressive relaxation } \\
\text { group. }\end{array}$ \\
\hline $\begin{array}{l}\text { Tabatabaee } \\
\text { et al. }(2016)\end{array}$ & $\mathrm{RCS}$ & $\begin{array}{l}90 \text { cancer patients receiving } \\
\text { chemotherapy ( } 30 \text { patients study, } \\
30 \text { patients placebo, } 30 \text { patients } \\
\text { control group) }\end{array}$ & $\begin{array}{l}\text { The study group received a total of } \\
\text { seven sessions of therapeutic touch for } \\
\text { four weeks; The placebo group was } \\
\text { placed around the body in a motion } \\
\text { away from the body for the same time } \\
\text { and was moved to touch without } \\
\text { specific order. The control group } \\
\text { received only standard chemotherapy } \\
\text { treatment. }\end{array}$ & $\begin{array}{l}\text { It was reported that therapeutic touch } \\
\text { positively affected patients physically and } \\
\text { psychologically, decreased pain level } \\
\text { significantly ( } \leq 0.05) \text { and was one of the } \\
\text { cognitive / behavioral methods that } \\
\text { increased in importance and use among } \\
\text { nurses in recent years. }\end{array}$ \\
\hline
\end{tabular}

\section{References}

[1] Yıldırım, Y. (2017). Palyatif bakımda hemşirelik çalışmaları. Türkiye Klinikleri J Anest Reanim-Special Topics, 10 (1), 4956. https://www.turkiyeklinikleri.com/article/tr-palyatifbakimda-hemsirelik-calismalari-77599.html

[2] Arslan Özkan, H. (2017). Hemşirelikte Bilim, Felsefe ve Bakımın Temelleri. İstanbul: Akademi Basım Yayınevi.

[3] Tarakçıŏlu, Ç. (2016). Onkoloji hemşireliğinde semptom yönetimi. Gümüşhane Üniversitesi Sağllk Bilimleri Dergisi, 5 (4), 93-100. Available from: https://www.researchgate.net/publication/309609614_Onkoloj i_Hemsireliginde_Semptom_Yonetimi
[4] Siegel, R. L., Miller, K. D., Jemal, A. (2017). Cancer statistics 2017. CA Cancer J Clin, 67 (7), 30. doi: $10.3322 /$ caac. 21387 .

[5] Cedar, S. H., White, M., Atwal, A. (2018). The efficacy of complementary therapy for patients receiving palliative cancer care. International Journal of Palliative Nursing, 24 (3), 14651. doi: 10.12968/ijpn.2018.24.3.146.

[6] Aydoğan, F., ve Uygun, K. (2011). Kanser hastalarında palyatif tedaviler. Klinik Gelişim, 24 (3), 4-9. Available from: http://www.klinikgelisim.org.tr/kg_243/2.pdf

[7] Ehsani, M., Taleghani, F., Hematti, S., et al. (2016). Perceptions of patients, families, physicians and nurses regarding challenges in cancer disclosure: A descriptiv equalitative study. European Journal of Oncology Nursing, 25, 55-61. doi: 10.1016/j.ejon.2016.09.003. 
[8] Yıldırım, Y. K., Uyar, M., Fadıloğlu, C. (2005). Kanser ağrısı ve yaşam kalitesine etkisi. $A \breve{g} r l, 17$ (4), 17-22. Available from: https://www.journalagent.com/agri/pdfs/AGRI-88598REVIEW-KUZEYLI_YILDIRIM.pdf

[9] Kim, K. S., Loring, S., Kwekkeboom, K. (2018). Use of artmaking intervention for pain and quality of life among cancer patients: A systematic review. Journal of Holistic Nursing, 36 (4), 341-53. doi: 10.1177/089801011772663.

[10] Beuken, V., Everdingen, V., De Rijke, J. M. (2007). Prevalence of pain in patients with cancer: A systematic review of the past 40 years. Ann Oncol, 18 (1), 1437-49. doi: 10.1093/annonc/mdm056.

[11] Kara, B., ve Fesci, H. (2008). Kanserde öz-bakım ve yaşam kalitesi. Hematoloji-Onkoloji, 6 (4), 124-29.

[12] Breivik, H., Cherny, N., Collett, B. (2009). Cancerrelated pain: a pan-European survey of prevalence, treatment, and patient attitudes. Ann Oncol, 20 (8), 1420-33. doi: 10.1093/annonc/mdp001.

[13] Uysal, N., Şenel, G., Karaca, Ş., et al. (2015). Palyatif bakım kliniğinde yatan hastalarda görülen semptomlar ve palyatif bakımın semptom kontrolüne etkisi. $A \breve{g r l}, 27$ (2), 104-10. doi: 10.5505/agri.2015.26214.

[14] Beuken, V., Van Everdingen, M. H., Hochstenbach, L. M., et al. (2016). Update on prevalence of pain in patients with cancer: Systematic review and meta-analysis. J Pain Symptom Manage, 51, 1070-90. doi: 10.1016/j.jpainsymman.2015.12.340

[15] Arslan, S., ve Çelebioğlu, A. (2010). Postoperatif ağr1 yönetimi ve alternatif uygulamalar. Uluslararası Insan Bilimleri Dergisi, 5 (1), 1-7. Available from: file://C:/Users/pc/Downloads/145-434-1-PB.pdf

[16] Sucaklı, M. H. (2014). Palyatif bakım ve yaşam kalitesi. Türkiye Klinikleri J Fam Med-Special Topics, 5 (3), 109-13. Available from: https://www.turkiyeklinikleri.com/article/trpalyatif-bakim-ve-yasam-kalitesi-69340.html

[17] Hökkä, M., Kaakinen, P., Pölkki, T. A. (2014). Systematic review: Nonpharmacological interventions in treating pain in patients with advanced cancer. Journal of Advanced Nursing, 70, 1954-69. doi: 10.1111/jan.12424.

[18] Ovayolu, Ö., ve Ovayolu, N. (2017). Palyatif bakım alan kanser hastalarının ağrı yönetiminde integratif yaklaşımlar. Journal of Hacettepe University Faculty of Nursing, 4 (3), 5464. Available from: http://hacettepehemsirelikdergisi.org/pdf/pdf_HHD_247.pdf

[19] Öztorun, H. S., ve Aras, S. (2018). Palyatif bakım nedir?. Türkiye Klinikleri Journal of Geriatrics-Special Topics, 4 (1), 1-6. Available from: https://www.turkiyeklinikleri.com/article/en-palyatif-bakimnedir-81299.html

[20] World Health Organization. (2008). World Alliance for Patient Safety Forward Programme 2008-2009. 1st ed. France; Available from: http://apps.who.int/iris/bitstream/10665/70460/1/WHO_IER PSP_2008.04_eng.pdf

[21] World Health Organization (WHO). (2017). Definition of Palliative Care. USA;. Available from: $\mathrm{http}: / / \mathrm{www}$. who.int/cancer/palliative/definition/en/
[22] Kabalak, A. A., Öztürk, H., Cağı̆l, H. (2013). Yaşam sonu bakım organizasyonu: Palyatif bakım. Yoğun Bakım Dergisi, 11 (2), 56-70. Available from: http://www.yogunbakimdergisi.org/managete/fu_folder/201302/html/2013-11-2-056-070.htm

[23] Kozier, B., Berman, A., Snyder, S., et al. (2008). Fundamentals Of Nursing Concepts, Process and Practice. 8nd.ed. New Jersey: Prentice Hall.

[24] Özveren, H. (2011). Ağr1 kontrolünde farmakolojik olmayan yöntemler. Hacettepe Üniversitesi Sağllk Bilimleri Fakültesi Hemşirelik Dergisi, 1 (1), 83-92. Available from: https://dergipark.org.tr/download/article-file/88510

[25] Aştı, A. T., ve Karadağ, A. (2016). Hemşirelik Esasları: Hemşirelik Bilim ve Sanatı. İstanbul: Akademi Basın ve Yayincilik.

[26] Başaranoğlu, G., Başaranoğlu M, Erden V, Delatioğlu H., et al (2006). The effects of valsalva manoeuvres on venepuncture pain. Eur $J$ Anaesthesiol, 23, 591-93. doi: $10.1017 / \mathrm{S} 0265021506000160$.

[27] Kılıç, M., ve Öztunç, G. (2012). Ağrı kontrolünde kullanılan yöntemler ve hemşirenin rolü. Firat Sağllk Hizmetleri Dergisi, 7, 35-51. Available from: https://www.researchgate.net/publication/288542856_Agri_ko ntrolunde kullanilan yontemler ve hemsirenin rolu

[28] Akça, N. K., ve Arslan, D. (2015). Hemodiyaliz tedavisi alan 65 yaş altı bireylerde ağrı ve baş etme yöntemleri. Türk Nefroloji Diyaliz ve Transplantasyon Dergisi, 24, 278-82. doi: 10.5262/tndt.2015.1003.04.

[29] Aslan FE. (2014). Ăgrl Doğası ve Kontrolü. Ankara: Akademisyen Tip Kitabevi.

[30] Demir, Y. (2016). Ağrı ve yönetimi. İçinde: Aştı, T. A., Karadağ, A., editörler. Hemşirelik Esasları: Hemșirelik Bilimi ve Sanatı. 1. baskı. İstanbul: Akademi Basın ve Yayınc1lı;;. ss. 625-62.

[31] Blyth, F. M., March LM, Nicholas MK, et al. (2005). Self management of chronic pain: A population-based study. Pain, 112, 285-92. doi: 10.1016/j.pain.2004.12.004.

[32] Bacaksız, D. B., Çöçeli, P. L., Ovayolu, N., et al. (2008). Hastaya bakım veren sağlık çalışanlarının ağrı kontrolünde uyguladıkları girişimlerin değerlendirilmesi. A 26-36. Available from: https://www.journalagent.com/agri/pdfs/AGRI_20_3_26_36.p df

[33] Guyton, A. C., \& Hall, J. E. (2001). Textbook of Medical Physiology. Philadelphia: W. B. Saunders.

[34] Satija, A., \& Bhatnagar, S. (2017). Complementary therapies for symptom management in cancer patients. Indian J Palliat Care, 23 (4), 468-79. doi: 10.4103/IJPC.IJPC_100_17.

[35] Pan, Y., Yang, K., Shi, X. (2018). Clinical benefits of acupuncture for the reduction of hormone therapy-related side effects in breast cancer patients: A systematic review. Integr Cancer Ther, 17 (3), 602-18. doi: $10.1177 / 1534735418786801$.

[36] Deng, G., Rusch, V., Vickers, A. (2008). Randomized controlled trial of a special acupuncture technique for pain after thoracotomy. Journal of Thoracic and Cardiovascular Surgery, 136, 1464-69. doi: 10.1016/j.jtcvs.2008.07.053. 
[37] Chen, H., Liu, T. Y., Kuai, L., et al. (2013). Electroacupuncture treatment for pancreatic cancer pain: A randomized controlled trial. Pancreatology, 13, 594-97. doi: 10.1016/j.pan.2013.10.007.

[38] Tofthagen, C., Boses, S., Healy, G., et al. (2015). Evaluation of group acupuncture for cancer-related symptoms: A retrospective analysis. Journal of Palliative Medicine, 18 (10), 878-80. doi: 10.1089/jpm.2015.0143.

[39] Chiu, H. Y., Hsieh, Y. J., Tsai, P. S. (2017). Systematic review and meta analysis of acupuncture to reduce cancer related pain. European Journal of Cancer Care, 26 (2), 24-57. doi: $10.1111 /$ ecc. 12457 .

[40] Price, S., \& Price, L. (2007). Aromatherapy for Health Professionals. Philadelphia: Elsevier Health Sciences.

[41] Buckle, J. (2015). Clinical Aromatherapy: Essential Oils in Practice. Philadelphia: Elsevier Health Sciences.

[42] Ceyhan, D, ve Yiğit, T. T. (2016). Güncel tamamlayıcı ve alternatif tıbbi tedavilerin sağlik uygulamalarındaki yeri. Düzce Üniversitesi Sağlık Bilimleri Enstitüsü Dergisi, 6 (3), 178-89. doi: 5000127982/5000179908.

[43] Bilgiç, Ş. (2017). Hemşirelikte holistik bir uygulama: Aromaterapi. Namık Kemal Tip Dergisi, 5 (3), 134-41. https://dergipark.org.tr/download/article-file/392598

[44] Babashahi Kohanestani, F., Ahmadi, F., Memarian, R. (2013). The effect of Lavender aromatherapy program on the pain intensity of patients with AML undergoing chemotherapy. Journal of Urmia Nursing and Midwifery Faculty, 11 (3), 1-10. Available from: http://unmf.umsu.ac.ir/article-1-1265-en.html

[45] Singh, P., \& Chaturvedi, A. (2015). Complementary and alternative medicine in cancer pain management: A systematic review. Indian Journal of Palliative Care, 21 (1), 105. doi: 10.4103/0973-1075.150202.

[46] Jibb, L. A, Nathan, P. C., Stevens, B. J., et al. (2015). Psychological and physical interventions for the management of cancer-related pain in pediatric and young adult patients: An integrative review. Oncology Nursing Society, 42 (6), 339. doi: 10.1188/15.ONF.E339-E357.

[47] Chen, T. H., Tung, T. H., Chen, P. S. (2016). The clinical effects of aromatherapy massage on reducing pain for the cancer patients: Meta-analysis of randomized controlled trials. Evidence-Based Complementary and Alternative Medicine. doi: 10.1155/2016/9147974.

[48] Doğan, H. D. (2014). Ellerin iyileştirme sanatı: Refleksoloji. Eur J Basic Med Sci, 4 (4), 89-94. doi: 10.15197/sabad.2.4.16.

[49] Uysal, N., ve Kutlutürkani, S. (2016). Kanserli bireylerde semptom kontrolünde refleksoloji uygulamas1. Bakırköy Tip Dergisi, 12, 103-9. doi: 10.5350/BTDMJB201612301.

[50] Stephenson, C. S., Nancy, L. N., Swanson, M., et al. (2007). Partner-Delivered reflexology: Effects on cancer pain and anxiety. Oncology Nursing Forum, 34 (1), 127. do1: 10.1188/07.ONF.127-132.

[51] Uysal, N., Kutlutürkan, S., Uğur, I. (2017). Kolorektal kanserli hastalarda iki farklı yöntemle uygulanan ayak masajının semptom kontrolü üzerine etkisi: Randomize kontrol calısması. Uluslararası Hemsirelik Uygulaması Dergisi, 23 (3), 25-32. doi: 10.5455/pmb.1-1406189204.
[52] Dikmen, H. A., ve Terzioglu, F. (2018). Effects of reflexology and progressive muscle relaxation on pain, fatigue, and quality of life during chemotherapy in gynecologic cancer patients. Pain Management Nursing. 20 (1), 47-53. doi: 10.1016/j.pmn.2018.03.001

[53] Tarrasch, R., Carmel-Neiderman, N. N., Ben-Ami, S. (2018). The effect of reflexology on the pain-insomnia-fatigue disturbance cluster of breast cancer patients during adjuvant radiation therapy. The Journal of Alternative and Complementary Medicine, 24 (1), 62-8. doi: 10.1089/acm.2017.0023.

[54] Tsay, S. L., Chen, H. L., Chen, S. C., et al. (2008). Effects of reflexotherapy on acute postoperative pain and anxiety among patients with digestive cancer. Cancer Nurs, 31, 109-15. doi: 10.1097/01.NCC.0000305694.74754.7b.

[55] Hodgson, N. A., \& Lafferty, D. (2012). Reflexology versus swedish massage to reduce physiologic stres and pain improve mood in nursing home residents with cancer: A pilot trial. Evid Based Compl Altern Med, 5, 1-5. doi: $10.1155 / 2012 / 456897$.

[56] Synder, M., \& Lindguist, R. (2010). Complementary/Alternative Therapies in Nursing. 6nd ed. Springer Publishing Company.

[57] Zhang, Y., Shen, C., Peck, K., et al. (2012). Training selfadministered acupressure exercise among postmenopausal women with osteoarthritic knee pain: a feasibility study and lessons learned. Evidence-Based Complementary and Alternative Medicine, 9, 1-9. doi: 10.1155/2012/570431.

[58] Li, W. L., Harris, E. R., Tsodikov, A., et al. (2017). Selfacupressure for older adults with symptomatic knee osteoarthritis: A randomized controlled trial. Arthritis Care \& Research, 6, 1-32. doi: 10.1002/acr.23262.

[59] Chien, L., Glick, R., Van Londen, G., et al. (2015). Auricular point acupressure to manage symptom clusters of pain, fatigue and disturbed sleep in breast cancer patients. The Journal of Pain, 16 (4), 110. do1: 10.4172/2167-0846.1000199.

[60] Sharif Nia, H., Pahlevan Sharif, S., Yaghoobzadeh, A. (2017). Effect of acupressure on pain in Iranian leukemia patients: A randomized controlled trial study. International Journal of Nursing Practice, 23 (2), 1-10. doi: 10.1111/ijn.12513.

[61] Serçe, S., Ovayolu, Ö., Pirbudak, L., et al. (2018). The effect of acupressure on pain in cancer patients with bone metastasis: A nonrandomized controlled trial. Integrative Cancer Therapies, 17 (3), 728-36. doi: $10.1177 / 1534735418769153$.

[62] Jane, S. W., Chen, S. L., Wilkie, D. J. (2011). Effects of massage on pain, mood status, relaxation, and sleep in Taiwanese patients with metastatic bone pain: A randomized clinical trial. Pain, 152 (10), 2432-4. doi: 10.1016/j.pain.2011.06.021.

[63] Toth, M., Marcantonio, E. R., Davis, R. B., et al. (2013). Massage therapy for patients with metastatic cancer: a pilot randomized controlled trial. J Altern Complement Med, 19 (7), 650-6. doi: 10.1089/acm.2012.0466.

[64] Cutshall, S. M., Mahapatra, S., Hynes, R. S. (2017). Hand massage for cancer patients undergoing chemotherapy as outpatients: A pilot study. The Journal of Science and Healing, 13 (6), 393-99. doi: 10.1016/j.explore.2017.06.007. 
[65] Sağkal, T., ve Eşer, İ. (2011). Hemşirelikte yeni bir uygulama: Reiki dokunma terapisi. Maltepe Üniversitesi Hemşirelik Bilim ve Sanatı Dergisi, (4) 1, 182-9. doi: 10.1155/2012/456897.

[66] Sağkal, T., Eşer, İ., Uyar, M. (2013). Reiki dokunma terapisinin ağrı ve anksiyete üzerine etkisi. Spatula $D D, 3$ (4), 141-6. doi: 10.5455/spatula.20131027113423.

[67] Demir, M., ve Can, G. (2013). Reiki. Sağlıkla Dergisi, 2, 56-7. Available https://www.researchgate.net/publication/236902810.

[68] Demir, M., Can, G., Kelam, A. (2015). Effects of distant reiki on pain, anxiety and fatigue in oncology patients in Turkey: A pilot study. Asian Pacific Journal of Cancer Prevention, 16, 4859-62. doi: 10.7314/APJCP.2015.16.12.4859.

[69] Kirshbaum, M. N., Stead, M., Bartys, S. (2016). An exploratory study of reiki experiences in women who have cancer. Int $J$ Palliat Nurs, 22 (4), 166-72. doi: 10.12968/ijpn.2016.22.4.166.

[70] Rosenbaum, M. S., \& Velde, J. (2016). The Effects of yoga, massage, and reiki on patient well-being at a cancer resource center. Clin J Oncol Nurs, 20 (3), 77-81. doi: 10.1188/16.CJON.E77-E81.

[71] Sánchez Domínguez, J. (2016). The gift of the application of reiki therapy in cancer patients. Rev Enferm, 39 (6), 38-49. Available from: https://www.researchgate.net/publication/309111612 THE G IFT_OF_THE_APPLICATION_OF_REIKI_THERAPY_IN CAN $\bar{N} \overline{\mathrm{R}}$ PATTENTS

[72] Çoban, A. (2005). Müzik Terapi. İstanbul: Timaş Yayınları.

[73] Keenan, A., \& Keithley, J. K. (2015). Integrative review: Effects of music on cancer pain in adults. Oncol Nurs Forum, 42 (6), 68-75. doi: 10.1188/15.ONF.E368-E375.

[74] Bradt, J., Dileo, C., Magill, L., et al. (2016). Music interventions for improving psychological and physical outcomes in cancer patients. Cochrane Database Syst Rev, 15 (8), 1-10 doi: 10.1002/14651858.CD006911.pub3.

[75] Bro, M. L., Jespersen, K. V., Hansen, J. B. (2018). Kind of blue: A systematic review and meta analysis of music interventions in cancer treatment. Psycho Oncology, 27 (2), 386-400. doi: 10.1002/pon.4470.

[76] Garza-Villarreal, E. A., Pando, V., Parsons, C., et al. (2017). Music-induced analgesia in chronic pain conditions: a systematic review and meta-analysis, Pain Physician, 20, 597-610. https://www.painphysicianjournal.com/current/pdf?article=NDcw Mw\%3D\%3D\&journal=108

[77] Lee, S. H., Song, E., Kim, S. K. (2015). Effects of oriental medicine music therapy in an ovarian cancer patient with soeum-type constitution: A case report. Integr Med Res, 4 (1), 48-52. doi: 10.1016/j.imr.2014.12.002.

[78] Jourt-Pineaua, C., Guétinb, S., Védrinea, L., et al. (2013). Effets de la musicothérapie sur la douleur et l'anxiété des patients atteints de cancer hospitalisés et/ou suivis en service d'oncologie. Douleurs: Evaluation - Diagnostic - Traitement, 14 (4), 200-7. doi: 10.1016/j.douler.2013.03.011.

[79] Lovejoy NC, Tabor D, Matters M, et al. (2000). Cancer related depression: neurologic alterations and cognitive behavioral therapy. Oncology Nursing Forum, 27 (4), 677-8. Available from: https://www.ncbi.nlm.nih.gov/pubmed/10833695
[80] Kreitzer, M. J., \& Sayder, M. (2002). Healing the heart: Integrating complemantary threapies and healing practices into the care of cardiovascular patients. Proggresive Cardiovascular Nursing, 17 (2), 73-80. doi: 10.1111/j.17517117.2002.tb00272.x.

[81] Boscaglia, N., Clarke, D. M., Jobling, T. W., et al. (2005). The contribution of spirituality and spiritual coping to anxiety and depression in women with a recent diagnosis of gynecological cancer. Int $J$ Gynecol Cancer, 15 (5), 755-61. doi: 10.1111/j.1525-1438.2005.00248.x.

[82] Choumanova, I., Wanat, S., Barrett, R., et al. (2006). Religion and spirituality in coping with breast cancer: Perspective of Chilean women. The Breast Journal, 12 (4), 349-52. doi: 10.1111/j.1075-122X.2006.00274.x.

[83] Frick, E., Riedner, C., Fegg, M., et al. (2006). Clinical interview assessing cancer patients' spiritual needs and preferences. Eur J Cancer Care, 15 (3), 238-43. doi: 10.1111/j.1365-2354.2005.00646.x.

[84] Anderson, K. O., Cohen, M. Z., Mendoza, T. R., et al. (2006). Brief cognitive-behavioral audiotape interventions for cancerrelated pain: Immediate but not long-term effectiveness. Cancer, 107 (1), 207-14. doi: 10.1002/cncr.21964.

[85] Kurt, B., ve Kapucu, S. (2018). The effect of relaxation exercises on symptom severity in patients with breast cancer undergoing adjuvant chemotherapy: An open label non-randomized controlled clinical trial. European Journal of Integrative Medicine, 22 (1), 54-61. doi: 10.1016/j.eujim.2018.08.002.

[86] Çöçelli, P. L., Bacaksız, D. B., Ovayolu, N. (2008). Ağrı tedavisinde hemşirenin rolü. Gaziantep Tıp Dergisi, 14 (1), 53-8. Available from: file://C:/Users/pc/Downloads/5000171278-5000442533-1PB.pdf

[87] İnal, S., ve Canbulut, N. (2015). Çocuklarda işlemsel ağrı yönetiminde dikkati başka yöne çekme yöntemlerinin kullanılmasi. The Journal of Current Pediatrics, 13 (1), 11621. doi: $10.4274 /$ jcp.29292.

[88] Aslan, F. E. (2012). Ağrı değerlendirme yöntemleri. Cumhuriyet Üniversitesi Hemșirelik Yüksekokulu Dergisi, 6 (1), 9-17. Available from: http://eskidergi.cumhuriyet.edu.tr/makale/598.pdf

[89] Aydın, A., ve Çilingir, D. (2016). Koroner arter baypas greft ameliyatı olan hastalarda nonfarmakolojik yöntemlerle ağrı yönetimi. Türkiye Klinikleri J Nurs Sci, 8 (2), 146-52. doi: 10.5336/nurses.2014-43196.

[90] Aghabati, N., Mohammadi, E., Esmaiel, Z. P. (2010). The effect of therapeutic touch on pain and fatigue of cancer patients undergoing chemotherapy. CAM, 7, 375-81. doi: 10.1093/ecam/nen006.

[91] Turan, N. (2015). Yoğun bakım ünitesinde terapötik dokunmanın önemi. Acıbadem Üniversitesi Sağlık Bilimleri Dergisi, 6 (3), 134-9. Available from: http://openaccess.acibadem.edu.tr:8080/xmlui/bitstream/handl e/11443/438/Derleme\%203.pdf?sequence=1\&isAllowed=y

[92] Tabatabaee, A., Tafreshi, M. Z., Rassouli, M., et al. (2016). Effect of therapeutic touch on pain related parameters in patients with cancer: A randomized clinical trial. Mater Sociomed, 28 (3), 220-3. doi: 10.5455/msm.2016.28.220-223. 